Przegląd Badań Edukacyjnych Educational Studies Review

ISSN $1895-4308$

nr 23 (2/2016), s. 105-124

METAANALIZY

BADAŃ

EDUKACYJNYCH

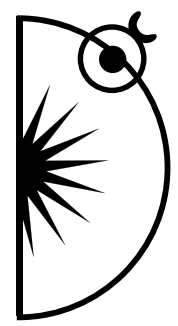

Erika Zolnai

University of Debrecen, e-mail: zolnai.erika@foh.unideb.hu

Lajos Hüse

University of Debrecen, e-mail: huse.lajos@foh.unideb.hu

Erzsébet Balogh

University of Debrecen, e-mail: balogh.erzsebet@foh.unideb.hu

Marzanna Farnicka

University of Zielona Gora, e-mail: m.farnicka@wpsnz.uz.zgora.pl

Vaclav Holecek

University of West Bohemia, e-mail: vholecek@kps.zcu.cz

\title{
Quality Versus Equality. The Integration as the Component of Primarly School's Excellence - a Cross-Cultural Perspective
}

http://dx.doi.org/10.12775/PBE.2016.075

\begin{abstract}
This study is about the continuous flaring debate how to measure the school's performance, how the integration efforts will be equivalent in addition to the absolute value of student performance. Contributors analyzed the international processes which determine the role of public education and its effectiveness both internationally and with special focus on Hungary. Authors tried to emphasize local characteristics and highlight how globalization processes are suitable for the performance of schools in V4 countries. In the article, there was also given a description of the paradigm shift in the Hungarian educational system and the role of the inclusive integrated school in the framework of Hungarian integration efforts. This Hungarian framework was compared with Polish, Czech and Slovak solutions. This work
\end{abstract}


could be instructive for educators based on the historical and societal similarities of these four countries.

Keywords: education system, equal chances, mainstreaming, inclusive education, special needs, minorities

\section{Introduction}

Studying the reform processes of the South American countries, Fukuyama (2008) claims that they repeat the same two methods that were unsuccessful in the developed countries: unsustainable expansive improvement and competition-oriented quality improvement, which increases the inequality of disadvantaged groups and ultimately propagates poverty. In the light of the new data (OECD, 2015; Hijzen \& Menyhert, 2016) this phenomenon seems to be manifesting in some post-socialist countries that joined the EU. In social performance, along with economic performance, the components of social cohesion (association, trust, crime) play an excessively important role. International research shows that income disparities, social and institutional trust, crime and educational inequalities are interrelated. According to Green, Preston and Sabates (2003) education affects the individuals' voluntary social/civic participation through cognitive, personal capability development, and through the status and network centrality acquired by qualification. The added value of education appears besides labor market and economic performance, in the social willingness to cooperate. As a result of this, social groups are capable of being recipients even in crisis, they voluntarily undertake community efforts (ex. taxes). The resilience, adaptability and democratic solutions are intensifying both on a personal and group level. Behind social inequalities, there are complex social processes (income disparities, residence etc.); educational inequality is simultaneously the manifestation, the cause and the consequence of the social inequalities (Green, Preston \& Sabates, 2003). It has been known since Bourdieu (1984; 1986) that in social and economic competition, different groups with various opportunities are not necessarily performing in accordance with their abilities. This applies to school performance too (Spatig-Amerikaner, 2012; Mayer, 2006; Alexander, Entwisle \& Olsen, 2001).

Rational economic decisions are not effective in solving several problems concerning globalization (environmental pollution, reasonable use of resources etc.); moreover, in this case moderation could mean competitive disadvantage. 
For the selection of the appropriate social and community behavior, a high level of personal abilities and social relations is mandatory, which by far exceeds the knowledge-creating function of educational institutions. It is no coincidence that in an economic crisis followed by a social crisis, the attention of both the developed and the developing countries is directed to social cohesion and the development of the national education system. In these education systems, equity is equally important as economic benefit. National and international experience shows that high quality education that is accessible to everyone contributes to the country's performance (Keller, Mártonfi, 2006).

The problems with changes taking place in the post-modernist era, were due to the fact that they involved the centers of identity and ideology, and even the system of values of education. For instance, the education systems of Western Europe put much emphasis on such values as autonomy and independence, while the systems in Asia emphasize the worth of mutual dependence and the sense of community. However, both systems promote the openness to the world, which is manifested for example by the fascination of young people with new cultures. That is why, in Europe, where the normative development is directed towards individualism, the fascination with another identity or ideology (i.e. the collectivistic one) sometimes emerges.

In educational practice, knowledge creation, the maximal unfolding of individual talent and the prevention of exclusion of disadvantaged groups often appear as different interests, mobilizing rival education management, organizational, technical and financial instruments (Györgyi, Kőpatakiné, 2012). The aspect of equity extends far beyond this, as the UNESCO's latest education research (2015) report emphasizes: "It is not enough to simply allocate more domestic resources to education; the resources must be equitably spent. This entails identifying and targeting public spending towards those groups furthest from meeting the EFA goals and avoiding spending the bulk of resources on education levels likely to only be accessed by the elite" (UNESCO, 2015: 257).

Therefore, schools are central platforms in the formation of social cohesion in social and community space, where diverse social groups can have contact with each other or have a positive or negative effect on each other's lives. The unimpeachable expectation of the participants is that interventions have a positive influence on social processes. Together with the quality of content, the main instrument of this is the realization of integration and inclusion in the education system, from kindergarten to adult education. Several objective and subjective factors influence the effectiveness of these pursuits. Without the understanding 
of these factors, neither the reform initiatives directed to the integration of the education system, nor their failures are comprehensible.

\section{The importance of integration and inclusion}

The authors' aim was not to give a detailed description of the conceptual history of the two definitions, but to show significant differences of interpretation in each of the linguistic areas. This is reflected in both the professional attitude and practices. The term integration is recently used, besides the traditional meaning, to mean the elimination of territorial and economic isolation, in connection with the realization of social integration and equal opportunities of disabled people. Lately, the definition of integration in education has been enriched with a much broader context: instead of the generally accepted, segregated, isolated and specialized education systems, from the beginning of the century, disability inclusion practices have turned up as reforms in education. Therefore, in this context, integration is closely related to segregation as the opposite, not only of preconceptions and moral isolation but even physical separation (Papp, 2012).

In the development of content, the Special Education System's change of attitude is well traceable from separation through mainstreaming to inclusion. In connection with the expression inclusion, Limbach-Reich (2015) observes that recently many consider the term inclusion a buzzword which could hardly explain the phenomenon. In education, Feuser $(1999,2002)$ uses the term when referring to Comenius. According to Feuser "inclusive education is a framework of learning that attempts to teach everything to everyone and within which everyone is invited to learn supported by the help he or she needs." (Feuser, 1999; 2002 cited by Limbach-Reich, 2015, p. 362). The inclusve school system can be described as a practice which provides available knowledge for all children with sufficient support and diversified, customized methods.

Persuant to the Salamanca Statement (UNESCO, 1994), schools have to adapt to the children's needs and abilities in physical, intellectual, social, emotional, linguistic and other areas. It also states that the inclusive approach needs to be extended from SEN children to all the students from ethnic or cultural minorities or from other disadvantaged groups. This statement forced the expansion of the inclusive education to all groups that have biological, ability-related, racial, ethnical or linguistic handicaps, or even stigmas.

The varoius groups above could be called minoritized groups. The term minoritized expresses the outcome of unequal circumstances both of society and school, marginalization and exclusion. As Bishop (2013, p. 74) explained: 
"To be minoritized one does not need to be in the numerical minority but only to be treatened as if one's position and perspective are of less worth: to be silenced or marginalised". Being minoritized strongly affects school efficiency. Despite numerous well-intentioned restructuration, reforms, and curricular efforts, many children who are in some way different from children of the dominant and traditional families do not achieve school success (Alexander, Entwisle, \& Olsen, 2001). Although various minoritized educational needs are not the same methodologically (e.g. ethnical vs. mentally handicapped), the lack of equity extends to all of them and the consequences of being minoritized can slip with their academic skills, so theoretical background of the integration/inclusion is exactly the same.

Integration and inclusion within education systems are intended to reduce disadvantages with pedagogical methods; and also to help groups with different starting opportunities to reach an optimal performance and learning experience. The education systems in each nation depart from different positions in this progress. The 'School for All' or 'Education for All' program has been started in the UK, but has already been adopted by many countries. For instance, UNESCO's program called 'Education for All' accordingly examined the education system development in 164 countries worldwide between 2000 and 2015. It evaluates educational equity along a number of dimensions, and compares the operation efficiency of different systems. Among several thought-provoking statements, it describes, in accordance with the role of decentralization, that it has a positive impact only in the case where local governments are in a good (financial) position. Otherwise, decentralization intensifies regional inequalities, like the free choice of schools can increase inequalities too.

\section{Educational inequalities in Hungary}

The educational inequalities hamper the success of school integration and inclusion. When differences occur between the school and the local government which are difficult to overcome, the acceptance and inclusion conditions of disadvantaged groups are also not equally given. The actors with the most optimal conditions will be the least open to integration. In Hungary, three educationrelated problem areas have been the focus of attention. One of these areas is the educational expansion, which leads to education devaluation and the unusability of lower skill levels on the labor market. Although the labor market and the payment advantages obtained by qualification have decreased, the absence of graduation and/or BSc degree have caused a severe disadvantage in the search 
for employment; it is still easier to find a job with a higher degree. The other neuralgic point is the exclusion of the Roma minority and the spread of school segregation especially in ghettoized settlements. The third problem area is the decline of performance indicators among students, particularly the social differences in access to high quality education.

The first PISA surveys drew attention to educational inequalities, but the specificities of the school system and the social practices are rooted in the 1980s' educational reforms which expanded in the 1993 Education Act. The widened decentralization, in addition to educational benefits, also increased inequality in many ways (triple autonomy: parents, school, maintainer). The school funds were heavily dependent upon the settlement size, the amount of money spent on education and, in the case of larger settlements, upon the interest enforcement capabilities of the parents and the educators. The financial deficiencies in education increased the differences of settlements and the satisfactory supply of school instruments. On one hand, the parents' free choice of schools directed the parents of higher status and with good interest enforcing skills towards schools that promised better opportunities in further education (e.g. specializations, special classes, 6 or 8 grade grammar schools). On the other hand, children from the lower educated and often disadvantaged social groups were left in schools burdened with financial and professional problems (benign segregation). Additionally, schools continued to enhance covert segregation with the possibility of student selection (covert admission, dismissal of troubled students, private student status).

The 1990s' segregated special education practice 'soaked up' not only the disabled children, but the majority of troubled children, struggling with learning, attention and behavioral difficulties from disadvantaged and/or Roma social groups. Several studies evinced how disproportionately Roma children appeared in special schools and later in small classes (Halász, Lannert, 2003). After the Equality Act and especially after the last peak of the demographic wave, schools defined themselves with different strategies. Some schools were specialized in the realignment of disadvantages (small classes), others specialized in school performance and the increase of further education chances (language, sport, music specializations etc.). Therefore, a particular, mosaic-structured education system has evolved (Eröss 2008); although its characteristics are unclear, the dispersion of students is still fairly consistent.

The children of socially disadvantaged and underqualified parents have the worst disadvantaged position in Hungary, from the school to the labor market (Kertesi \& Kézdi, 2005). The integrated education of SEN children with special, normative financing is attached to this system, but this more likely strengthens 
the stigmatization and the segregation that is integrated into the uncommon hierarchy of the Hungarian education system.

\section{The appearance of educational inequalities in educational performance indicators - the Hungarian perspective}

The values of school performance have slightly decreased compared to the previous measurement (2012), but it is only slightly below the OECD average. In Hungary, the ESCS Index, measuring school inequality is $50 \%$ higher than the OECD average (HU 31.2\% OECD 20.7\%). This shows that in Hungary, the family, social, economic and cultural factors influence a child's school performance to a greater extent. The achievements of both the schools and the students are influenced by family background indicators (78\%).

The school performance of the students is highly dependent upon the quality of the school. However, within schools, the social indicator that signifies the school variance of the students is generally low. The reasons can be the segregation/detachment of the living environment, the selective school choice and homogenized pursuits within schools (capability and/or social dissociation between schools, school types or classes). This segregation has hardly shown any changes (Havas-Zolnay, 2011; Kertesi-Kézdi, 2005, 2008, 2011; Papp, 2011; Varga, 2009).

Another important fact is that there is a high rate of low achievers, those who cannot even reach the minimum level for education - critical reading quality, limited capability of independent information. There is a high rate of early school leavers which is amplified by the decrease of compulsory education age to 15 years of age. In disadvantaged groups there is a low rate of further education, this leads to the reproduction of employment disadvantages. It is necessary to separately examine a small number of resilient students $(<4 \%)$ in the Hungarian sample. These students show high performance and good adaptation skills despite their social disadvantages (ESCS lower by $25 \%$ with the school performance of the upper $25 \%$ ). To summarize, we can declare that the Hungarian education system amplifies the disadvantages already existing at the time of admission; it is not able to compensate for the influences of the family background; it does not meet reasonable operating conditions. The solutions are certainly the results of the selection mechanisms which lead to the localization of the learning problems through the educators' depletion of instruments, the contraselection of teachers, limited financial resources and negative feedback (Csapó et al. 2012). 


\section{Integration and inclusion in the case of students with Special Educational Needs}

According to Bánfalvy (2009), the integrated education practice of the disabled and SEN children has rapidly flooded the educational sector. Between 2002 and 2006 the number of integrated educated SEN children increased from 18 to 31000 , and, although it is well below the 50\% rate, the education system is not prepared for their acceptance. Both the material and the personal conditions are missing for an integrated education system (Halász, Lannert, 2003); not surprisingly in 2005, the majority of special need teachers did not agree with integration (Balázs, Bass, 2005). Almost 10 years laters in a 2014 study, the accepting educators unanimously reported that they did not get enough support from either the school management or from the maintainer during the integration. The more successful institutions attached less importance to the family factor, but more to educators, their professionalism and methodological diversity. The skeptical pedagogues often reported on negative and prejudicial behavior that came from other children (Szabó, 2014).

As mentioned above, the lack of equity extends to various minoritized groups such as the Roma or the mentally handicapped. The category of SEN accumulates a large amount of Roma children who have learning disabilities primarily based on the marginalization and exclusion of their families.

\section{The challenges of the Roma integration in Hungary}

Taking under consideration the segment of Roma studies directed to the school environment, we see that the recovery of the social, education-political and sociological interests related to the educational disadvantages of Roma children, takes place during a period when Roma children are entering the education system in a greater proportion than ever before, and stay longer in that system than ever (Nagy, 2002). Ilona Laskó establishes that "Essentially, it is only the 1990s' development that Roma children massively and permanently attend to primary school and many of them finish their primary school studies" (Liskó, 2001, p. 3). Green (1980), who described the same phenomenon refering to the situation in the USA two decades ago, saw the solution in the expansion of education, and in the unexpected, accompanying consequences of this expansion. Green also writes that the higher the number of children of one generation who perform successfully at a given school level, the lesser the value of their qualifications. Therefore, when almost everyone performs at the given school level, 
almost no social benefit can be detected. However, it also dramatically increases the social risk of not performing at this devaluated school level (Green, 1980 cited by Nagy, 2002).

In Hungary, completing the primary school level has practically become this kind of qualification now, without social benefits. The rate of Roma students completing primary school has never been as high as it is today, however this qualification in the labor market is completely valueless. Besides the fact that the completed 8 grades entitles the students to further education, its labor market value is the same as an incomplete primary school degree, so practically it affects the direction of public work or unemployment. But the devaluation of education levels has not stopped at this level since the secondary education has already almost completely extended to the given generation. However, in the case of Roma students, the dropout rate is still excessively high.

Hajdú, Kertesi és Kézdi (2014) gave the first report on the secondary school careers of the Hungarian Roma students which is based on a complete, nation-wide representative sample. The grade chosen to the career monitoring enrolled in the secondary school in the Fall of 2006, and could optimally complete their studies in the Spring of 2012. During the $6^{\text {th }}$ school year, almost $90 \%$ of the sample group could gain qualification. A little bit more that $10 \%$ of the students dropped out, and were not able to obtain qualification or graduation. These failed school careers disproportionately characterize Roma students in Hungary. Almost a half of Roma students who started their studies in the Fall of 2006 were dropped out by the end of the sixth grade, about $30 \%$ gained qualification, and only $25 \%$ could earn graduation.

The most important statement of the mentioned research was that the significant ethnic differences, detected at the end of the secondary school career, were related to the severe deficiencies in the basic skills obtainable in primary school. The causes of these problems can trace back to early childhood. While most knowledge deficiencies arise in early childhood and in primary school, they can also be the most efficiently prevented at that age (Hajdú, Kertesi, Kézdi, 2014).

Another impact of qualification on the labor market can be observed in income differences. The revenues of the higher education qualified people exceed secondary school qualifications by far, within this both the secondary and high qualifications are characterized by a high dividend income rate in Hungary. But this does not occur in the high income rate of those professional qualifications, but in the low income rate of lower qualifications. Therefore, in Hungary, the impact of education is outstanding. In other words, in the case of lower edu- 
cated people there is a huge backlog which, given a low average employment rate, causes severe social problems (Györgyi, 2014). These are complex problems typical in low educated groups which are not manageable by the systems reserved for this purpose (like social, child protection systems, and partially the education and health care systems).

As it is negotiated in many studies, one of the most significant exclusion sites is the education system. Although in modern societies, in conservative or liberal democracies, and also in the former socialist model, the declared purpose of the education system is to decrease social differences. In fact, it can easily happen that practices of the given education system increase the inequality and intensify the exclusion. The results of the PISA survey show that in countries with Prussian education traditions, schools conserve and deepen the disadvantages arising from the social status of the families. From 15 examined countries, in the Czech Republic, in Austria, in Germany and in Hungary there were the greatest differences between the average results and the results of the children coming from families with a lower social and/or financial status (Róbert, 2004). The selectivity of the Hungarian education system has gone so far that today the Hungarian one is one of the most segregated school systems in the world. In this country, children from different social groups are the furthest separated from each other both at school and at class level (Kertesi, Kézdi, 2012; Radó, 2007).

In schools the majority of Roma children face a dual disadvantage: on the one hand, with the disadvantages originating from their social backgrounds, on the other hand, with the discrimination and negative perceptions that the majority of the environment produces about the ethnicity. More than $80 \%$ of Roma children are disadvantaged, about two thirds of them are severely disadvantaged; that means that 4 out of 5 Roma children are fighting social disadvantages and extreme financial and intellectual deprivation. The exclusion has a negative influence on children's mental and cognitive developments, and on the formation of their social skills. This is the reason why the function of modern societies' school systems is not only to transfer current and valid knowledge, but to decrease the disadvantages and inequalities of their social background (Messing, Molnár 2008).

Most Roma children suffer from disadvantages parallel to poverty which originate from prejudicial, often discriminative reactions of the majority of the environment. Mária Neményi (2007b) analyzed how to affect self-image, selfesteem, school performance and further education ambitions of Roma children despite the negative, degrading attitude of the majority of the environment and the low expectations of the teachers and environment towards them. The re- 
search reveals that a significant part of Roma children experiences their ethnicity as a threat. These children are familiar with the stereotypes created by the majority of the society about the Roma. These stereotypes are inevitably integrated into the identity of these children, and this has a great effect on their personality and on the image formed by their environment.

The stereotypes, flowing unlimitedly in the society, the media and unfortunately in schools, function as self-fulfilling prophecies. Thanks to prejudices, the environment "knows" the Roma children are "stupid", "talentless", and "the parents do not give support, so it is useless to deal with them" (Neményi 2007a). In an environment like this, it is almost natural that even the most talented children do not perform well, moreover, and this is a more serious problem, they believe themselves to be talentless and completely unsuited to fulfill any further ambitions after primary school (Neményi 2007b). The destructive effect of stereotypes and exclusion has already been confirmed by studies (Kertesi, Kézdi 2004, p. 12; Hüse et al, 2014).

Neményi (2007b) declares that segregated education has disadvantages not even for Roma students but also for non-Roma students learning in a segregated class: in the case where the rate of Roma students exceeds a critical level, academic achievement and further education ambitions highly decrease among both Roma and non-Roma children. This phenomenon is well observed by the parents of non-Roma children (cf. Kertesi, Kézdi, 2012). Therefore, from their point of view, it is a rational decision to take their children out from a school where the majority of students are the Roma.

Returning to Maria Neményi's research, it is particularly well documented in the sense that the (negative) correlation between the educational success and the rate of Roma children within the class cannot be traced back to any ethnic feature. Data proves that the reduction of school performance and further education ambitions are equally typical to Roma and non-Roma students; meanwhile the middle-class Roma parents also try to take their children ito another school (Neményi, 2007b). We might say that all the disadvantages and problems which are attributed to "the ethnicity" are actually the outcome of the school segregation process occurring at the institutional level.

Neményi (2007b), as well as Kertesi and Kézdi (2012) lay down that segregating schools provide a lower quality of service and education in every aspect than the schools avoiding segregation. Teaching in a segregated school means a stigma for teachers rather than a professional challenge. Although the social reasons (persistent poverty, low qualification level of parents, lack of permanent job and/or income, norms within the family different from the generally ac- 
cepted) are regularly present in the professional discussions and also in public discourses, the reasons which raise the responsibility of the educational institutions and also raise the possibilities of schools developing their integration efforts, are less well-known.

\section{The discussion with the Hungarian way. A Czech sample of coping with adaptation to school of Roma children}

This part is based on the analysis prepared by Holecek and Farnicka (2014). The main aim of the study was show the Czech strategy to solve problems with Roma children at schools. After the November revolution of 1989, a political movement was founded, the so-called ROI - Romská občanská iniciativa (The Roma Civic Initiative), which identified itself with the principles of equality, humaneness, humanity and freedom of religion. In the table below, figures apply only to the territory of the Czech Republic.

Table No. 1: The development of the number of Roma inhabitants in censuses

\begin{tabular}{|c|c|c|}
\hline date of the census & total inhabitants of the CR & Roma nat. \\
\hline 1991 & $10,302,215$ & 32,903 \\
\hline 2001 & $10,230,060$ & 11,746 \\
\hline 2011 & $10,562,214$ & 5,199 \\
\hline
\end{tabular}

Source: Czech Statistical Office 2014. [online] [quote 2014-07-07]. Available at: http://www.czso.cz/csu/2012edicniplan. nsf/t/9200475FB6/\$File/pvcr061.pdf

The sociological, but also psychological aspect of the development of the numbers of Roma identifying openly with the Roma ethnicity in censuses is also quite interesting. It is clear that in the past 30 years, the population of the Czech Republic is stable (a little over 10 million), while the numbers of members of national minorities varies widely.

In 1997, by decree of the government of the CR, a so-called interdepartmental commission for the Roma community issues was created, which, in 2001, transformed itself into an advisory body of the government of the CR, called: "Rada vlády pro záležitosti romské komunity" (Government Council for the Issues of the Roma Community). The Council systemically helps with the integration of the Roma into society. It collects, discusses and submits to the government information, groundwork and proposals for the creation and implementation of government policies that concern the Roma. The key docu- 
ments of the Council are the "Koncepce romské integrace" (Concept of Roma Integration) and the "Zpráva o stavu romské menšiny v České republice" (Situation Report of the Roma Minority in the Czech Republic). In many places, the governmental organization called "Agentura pro sociální začleňování v romských lokalitách" (Agency for Social Integration in Roma Locations), is doing successful work. Nevertheless, in general, it can be said that the solving of the co-called Roma question is largely unsuccessful, because a lot of Roma children drop out from the education system or are qualified to special education not because of intellectual disabilities but lack of communication skills and lack of motivation.

Attempts have to be made to look for new bases for different strategies for solving the Roma question, strategies somewhat different from the present ones.

It is therefore quite logical that the very often inadequate and for the Czech incomprehensible behavior of the Roma is a result of many previous experiences and existential sufferings, to which they were subjected. Due to the decrease in existential stress factors, the Roma acquired certain behavioral patterns that do not allow them to escape their social exclusion. These behavioral patterns, however, do not, on the other hand, guarantee the preservation of mental integrity, which seems to be an essential positive factor for survival at a group as well as individual level. Unfortunately, these behavioral patterns are very often incompatible with the generally accepted values of the majority of the society.

The question is, e.g. how much did our current majority education system contribute to the present situation? Despite the carried-out curricular reform, which put emphasis on creating key competences (instead of traditional knowledge), our education system is still too encyclopaedically, academically oriented. This orientation then provides the best opportunities for success to children coming from a more educated environment. A bad start of Roma children at school then creates the basis for further problems, which are already well known. The vicious cycle can be escaped through conscious help in places where it is needed, such as schools (Farnicka, 2014).

The fact that the causes of the social exclusion of the Roma lie somewhere completely else is confirmed by the unequivocal fact that despite the enormous effort of all the governments, which were addressing the Roma question, these efforts never had any significant effect and they definitely did not bring about any systemic improvement. On the contrary, the result of this effort is an ethnic tension, growing anti-gypsyism and the complete incapacity of most of the Roma to integrate into the majority of the society. The approaches pushed and practiced on the Roma by the government of the Czech Republic have, so far, 
been quite ineffective. They are built on the assumption that the Roma problem is a social problem. The social exclusion, however, is just the consequence of the situation in which the Roma have been for centuries.

On the $14^{\text {th }}$ May 2014 the authorities of the Czech Republic government have publicized the working version of the so-called "Strategie romské integrace do roku 2020" (Strategy for Roma Integration till 2020).

The purpose of the strategy is to create a framework for measures, which will lead, till 2020, to the reversal of the negative development trends of the situation of the major part of the Roma in the CR in the fields of inclusion, education, employment, housing, health and society. An integral part of the strategy is its connectedness to the policies implemented or coordinated at the EU level, and at the same time to international initiatives, in particular within the Council of Europe, to the Dekáda romské inkluze (Decade of Roma Inclusion) initiative and to the recommendations of control mechanisms of the UN.

The strategy should introduce new paradigms that will allow to create a basis for the search for new strategies for solving the Roma question, for strategies with a real chance for a lasting success. The direction showing the solution of the "Roma question" should be applicable in the whole Europe, not only with regard to the relations with the Roma, but, to a certain extent, it should be possible to extend it to the problems of other national minorities or to new immigrants from other cultural and religious regions. It is really necessary not only to criticize, but also to attempt to find ways of not only solving the Roma question, but also how to actually solve it, because the population of the Roma is dramatically growing. Therefore facing these problems and new with immigrants from East countries involved in creation of the European system of education, multiculturalism and the sense and values of education should be re-defined in the future.

\section{Slovak way to cope with educational problem children from ethnic minorities}

In connection with the preparation of the teacher's assistants, there is realized even a supportive educational intervention of teachers working with Roma children and children from the less stimulating social environments in the form of specialized innovative studying. Education of these teachers was to provide a compliant acceptance of both professional groups and to co-ordinate their pedagogic and educational function in the intentions indicated in the quoted works. The need of this intervention was confirmed by the results of the research 
which was realized before and during the realization of the study program with the aim of monitoring and evaluating the implemented innovations (Kasacova and Karikova, 2014). According to Kasacova and Karikova's research it can be stated that in Slovakia:

- existing differences between the opinion of the in-service teachers and of university teachers have a significant value in some cases;

- in comparison with the overall pattern, the assistants in practice and studying ones, students of teaching colleges etc. reduce these differences (they are in the middle)

- the largest disagreements are especially in the specific knowledge and skills - these are the areas which specifically differ the study program for the teacher assistants from the "obligatory" program

The proposed ways to cope with this problems were related to education. One of the examples was a study program Preschool and elementary pedagogy of socially disadvantaged groups at PF UMB in Banská Bystrica. The study program brings also another qualitative element, which consists in the understanding of position and function of teacher assistants in a wide socio-cultural context.

\section{Polish way of solving problems with educational inequalities}

In Poland a lot of problems with children with special needs were taken under consideration, but the problem of Roma or any other minority is not discussed separately. In many cases the main role in solving problems are parents, who are obliged to do their best to prepare the child to school. This is especially important since every child, whether they want it or not, is obliged to be educated in a chosen school. A peculiar group at school are children labelled as "others", for example rejected by peer groups, teachers, with a sense of loneliness, lack of the sense of security or with problems in educational success. It is worth mentioning and remind that the absence of the sense of security at school and in family is an important factor of psycho-social exclusion (rejection) (Gajewska, 2002). Potentially, children from foster-care families, children from minorities, children with a lack of school success are more exposed to it, and it is worth to underline that talented students are as well (Farnicka \& Liberska, 2015).

Psycho-social support at school and inclusion education may also be understood as an accumulated subjective sense of fulfillment of eight psycho-social needs (safety, support, acceptation). Care-givers', parents' or teachers' sense of threat affects the safety of children they educate and are taking care of, but also 
the opposite (reverse) relation can be noticed - the safety of children influences the sense of threat of their care-givers (Gajewska, 2014). It it worth to mention that in Polish schools, there are professionals to cope with this problem such as: psychologists, accompanying teachers (teacher assistants), school pedagogists, and in each case work-groups focused on problems with inequalities and possibilities of social and even material support.

\section{Summary}

In the post-modern society with the challenges of globalization, social differences are generated, become larger and larger to constitute a barrier to further social improvement. In public education, local experts and politicians working in education in the European Union have to face the fact that schools are less able to reduce social differences. The solution of social challenges requires a high level of development of the participants' practical skills and abilities and also better academic knowledge. One of propositions is Bennett model (1998). The process of integration and acculturation requires the engagement of many abilities at the level of behavior and teaching some interpersonal skills and control psychological processes in groups. Bennett based the way of changes on 6 stages: denial, defense, minimalization, difference acceptation, adaptation and integration. The final and most important stage is integration. In the integration process the individual is or is not able to see the 'crossing points'. The process of integration needs a greater range and goes deeper into the mental structure than the process of adaptation. It includes processes of identification, requiring the engagement of cognitive and evaluative structures. as well as assimilation and accommodation. The outcome of those processes is a change in self-definition, self-evaluation, evaluation of the individual's ethnic group and also in attitudes towards others (Kosíková, Liberska, Farnicka, 2014).

This study focuses on theoretical models and practical solutions of the integration and inclusion in public education in V4 countries. The disadvantages of minoritized groups seem quite clear both in international and Hungarian circumstances. The lack of equity has affected exclusion: the greatest losers of this process were the Roma in Hungary and Central Europe. While the direct burdens of inequity weigh on Roma, the labor market and the economy started lagging for EU, and the racism rose in society. However, there is a lot of literature on inclusion and the importance of equal opportunities is clear, the competition of resources that remained in the post-socialist society entered the school ruled by middle-class-culture, and educators and schoolmates socialized into this cul- 
ture: the minoritized children who are immersed in it have to face isolation. According to the authors, the only way is developing skills which are focused on integration among children and teachers.

\section{References:}

Alexander, K.L., Entwisle, D.R., Olsen, L.S. (2001), Schools, achievement, and inequality: A seasonal perspective, Educational Evaluation and Policy Analysis, 23(2), pp. 171-191.

Balázs J., Bass L. (2005), gyógypedagógus pályatükör A gyógypedagógusok pályaútja és társadalmi helyzete, Szociális Munka, 2005/3, p.3-17.

Bánfalvy Cs. (2009), A fogyatékos emberek iskolai integrációjáról, „Esély”2009/2, pp. 3-16.

Bennet J. (1986), A developmental approach to training intercultural sensitivity, in: J. Martin (ed.), Special Issue on Intercultural Training, International Journal of Intercultural Relations, 10 (2): pp. 179-186.

Bishop, R. (2013), Indigenous and other minoritized students, in: Hattie, J., Anderman, E.N. (eds), International Guide to Student Achievment, Routledge, New York, pp. 74-76.

Bourdieu, P. (1984), Distinctions. A Social Critique of the Judgment of Taste, Harvard University Press, Cambridge.

Bourdieu, P. (1986), The forms of capital, in: Richardson J. (Ed.), Handbook of Theory and Research for the Sociology of Education, Greenwood, New York, pp. 241-258.

Czech Statistical Office 2014. [online] [accessed on 2014-07-07]. Available at: http://www. czso.cz/csu/2012edicniplan.nsf/t/9200475FB6/\$File/pvcr061.pdf

Csapó, B., Fejes J.B., Kinyó L., Tóth E. (2012), Az iskolai teljesitmények alakulása Magyarországon nemzetközi összehasonlitásban, TARKI, Budapest.

Erőss, G. (2008), Mozaik Magyarország felfedezése, avagy az esetlegesség uralma, in: Berényi E., Berkovits B., Erőss G, AZ iskolába rendezett gyerek - kiváltság és különbségtétel a közoktatásban, http://real.mtak.hu/1676/1/47040_ZJ1.pdf

Farnicka M. (2014), Future perspectives as a condition of positive adaptation of young adults after traumatic experience, „Current Issues in Personality Psychology”, 2(3), pp. $164-170$.

Farnicka, M. Liberska H. (2015), Uwarunkowania poczucia dobrostanu psychicznego u dzieci w środowisku szkolnym, „Problemy Wczesnej Edukacji”, 4 (31), pp. 77-92.

Fukuyama, F. (2008), Falling Behind: Explaining the Development Gap between Latin America and the United States, Oxford University Press, Oxford. 
Gajewska G. (2002), Edukacja środowiskowa w przestrzeni życiowej dzieci i młodzieży: środowisko edukacyjne a poczucie oparcia dzieci i młodzieży - studium pedagogiczne, Wydawnictwo Edukacyjne Akapit, Torun.

Gajewska G. (2014), Children's Sense of Safety under Different Forms of Care at School and Where They Live, in: H. Liberska \& M. Farnicka (eds.), Child of many Worlds: Focus on the Problem of Ethnic Minorities, Peter Lang Edition, Frankfurt am Main, pp. 129-139.

Green, A. Preston, J. Sabates R. (2003), Education Equality and Socila Cohesion: A Distributional Model The Centre for Research on the Wider Benefits of Learning Institute of Education, http://eprints.ioe.ac.uk/5502/1/Green2003Education.pdf

Green, Th.F. (1980), Predicting the behavior of the educational system, Syracuse, New York.

Györgyi Z. (2014), Az oktatás eredményei, haszna, megtérülése, in: Széll K. [szerk.], Az OECD az oktatásról - adatok, elemzések, értelmezések, Oktatáskutató és Fejlesztő Intézet, Budapest, pp. 29-40.

Györgyi Z., Köpatakiné Mészáros M. (2012), Oktatási egyenlőtlenségek és sajátos nevelési igények, in: Jelentés a magyar közoktatásról 2010. Oktatáskutató és Fejlesztő Intézet. http://www.ofi.hu/kiadvanyaink/jelentes

Hajdu T, Kertesi G, Kézdi G. (2014), Roma fiatalok a középiskolában: beszámoló a TÁRKI Életpálya-felmérésének 2006 és 2012 közötti hullámaiból, in: Kolosi T., Tóth I. Gy. (szerk.): Társadalmi Riport 2014. Budapest, TÁRKI. pp. 265-302.

Halász, G. Lannert, J. szerk. (2003), Jelentés a magyar közoktatásról Országos Közoktatási Intézet, Budapest.

Havas G. - Zolnay J. (2011), Sziszifusz számvetése, „Beszélő” 16(6), pp. 24-49.

Hijzen, A., B. Menyhert (2016), Measuring Labour Market Security and Assessing its Implications for Individual Well-Being, OECD Social, Employment and Migration Working Papers, No. 175, OECD Publishing, Paris. DOI: http://dx.doi.org/10.1787/5jm58qvzd6s4-en.

Holeček, V. Farnicka M. (2014), National Minorities with a Focus on the Roma Problem and its Historical and Social-Psychological Aspects, in: H. Liberska \& M. Farnicka (eds.), Child of many Worlds: Focus on the Problem of Ethnic Minorities, Peter Lang Edition, Frankfurt am Main, pp. 67-83.

Hüse L., Balogh E., Barnucz N., Fónai M., Zolnai E. (2014), The discourse of social exclusion and its benefits for the majority, in: Liberska, H., Farnicka, M. [eds.], A Child of many Worlds: Focus on the Ethnic Minority Problem, Peter Lang, Frankfurt am Main, pp. 47-66. 
Kasacova and Karikova (2014), Keller J., Mártonfi Gy. (2006), Oktatási egyenlötlenségek és speciális igények, in: OKI. Jelentés a magyar közoktatásról (2006), Országos Közoktatási Intézet: pp. 377-413.

Kertesi G. - Kézdi G. (2009), Általános iskolai szegregáció Magyarországon az ezredforduló után, „Közgazdasági Szemle”, LVI. évf. 11. sz., pp. 959-1000.

Kertesi G. - Kézdi G. (2012), Ethnic segregation between Hungarian schools: Long-run trends and geographic distribution, „Budapest Working Papers On The Labour Market", No. 8.

Kertesi G., Kézdi G. (2005), Roma children in the transformational recession: Widening ethnic schooling gap and Roma poverty in post-communist Hungary, Budapest Working Papers on the Labour Market, BWP No. 2005/8.

Kosíková V. Liberska H. \& Farnicka M. (2014), Formative function of assessment in a psycho-didactical context, „Polskie Forum Psychologiczne”, 19, nr 1, 7-16.

Limbach-Reich, A. (2015), Reviewing the Evidence on Educational Inclusion of Students with Disabilities: Differentiating Ideology from Evidence, „International Journal of Child, Youth and Family Studies" 2015/ 6(3), pp. 358-378.

Liskó I. (2001), A cigány tanulók és a pedagógusok, Iskolakultúra 11-12, pp. 3-14.

Mayer, J. (2006), Az első, a második és az n-edik iskolai esély (hátrányos helyzetü tanulók iskolai kudarcai és a kompenzáció lehetőségei), „Új pedagógiai szemle” 56(12), pp. 37-54.

Messing V., Molnár E. (2008), ,....több odafigyelés kellett volna...” - A roma gyerekek iskolai sikerességének korlátairól, „Esély” 2008/4, pp. 77-93.

Nagy M. (2002), Cigány tanulók az iskolában. A tanárok beszélnek, „Magyar Pedagógia” 102/3, pp. 301-331.

Neményi M. (2007a), ...igen, vannak cigányok. Identitás-változatok tizenéves roma gyerekek szülei körében, „Esély” 2007/4, pp. 37-52.

Neményi M. (2007b), Az iskolai esélyek társadalmi meghatározottsága. Kutatási zárótanulmány.

OECD (2015): Education Policy Outlook 2015: Making Reforms Happen. OECD Publishing. DOI: http://dx.doi.org/10.1787/9789264225442-en.

Papp G. (2012): Az integráció, inklúzió fogalmak tartalmi elemzése gyógypedagógiai megközelitésben nemzetközi és magyar szintéren, Gyógypedagógiai Szemle 2012(4) http:// www.prae.hu/prae/gyosze.php?menu_id=102\&jid=41\&jaid=602.

Papp Z. A. (2011), A roma tanulók aránya Magyarországon és a tanulói teljesitmények az 
általános iskolai oktatásban, in: Bárdi N. - Tóth Á. szerk.: Asszimiláció, integráció, szegregáció: párhuzamos értelmezések és modellek a kisebbségkutatásban, Argumentum, Budapest, pp. 224-267.

Radó P. (2007), Oktatási egyenlőtlenségek Magyarországon, „Esély” 2007/4, pp. 24-36.

Róbert P. (2004), Iskolai teljesitmény és társadalmi háttér nemzetközi összehasonlitásban, in: Kolosi T., Tóth I. Gy., Vukovich Gy. (szerk.): Társadalmi riport, TÁRKI, Budapest, pp. 193-205.

Spatig-Amerikaner, A. (2012), Unequal Education: Federal Loophole Enables Lower Spending on Students of Color, Center for American Progress, Washington.

Szabó D. (2015), Utazó gyógypedagógiai szolgáltatás a résztvevők oldaláról, „Iskolakultúra" 2015/5-6, pp. 74-92.

UNESCO (1994), The Salamanca Statement and Framework for Action on Special Needs Education, Printed in UNESCO. http://www.unesco.org/education/pdf/SALAMA_E. PDF

UNESCO (2015): Education of All 2000-2015: Achievments and Challenges. Global Monitoring Report, UNESCO Publishing. http://unesdoc.unesco.org/images/0023/002322/232205e.pdf

Varga J. (2009), A tanárok elosztása a különbözö szociokulturális hátterü tanulókat tanitó iskolák között, in: Fazekas K. szerk.: Oktatás és foglalkoztatás, MTA KTI Budapest, p. 65-83. 